\title{
Modelling the Factor Influencing the Implementation of Mobile-Heutagogical Practices among Teachers: An Application of Invariance Multi-Group Structural Model
}

\author{
Kung-Teck, Wong* \\ Sultan Idris Education University, Perak, Malaysia. \\ Mohd Azli Yeop \\ Sekolah Menengah Sains Sultan Mohamad Jiwa, Kedah, Malaysia \\ Mazura @ Mastura binti Muhammad \\ Sultan Idris Education University, Perak, Malaysia
}

\begin{abstract}
The purpose of the study is to identify factors that influence behavioral intention (BI) of teachers in the developing of the MoblieHeutagogical (m-Heutagogical) Acceptance and Use Model. Many recent surges in published studies have revealed that m-Heutagogy has significant impacts on Edu. 4.0. However, the integrations seem to face a low level of its use among educators in the Malaysia setting. Methodologically, the study used the quantitative approach. A selfadministered survey was conducted involving 246 teachers, who were randomly selected from several teacher institutions and universities, where $58.1 \%$ (143) of the respondents were pre-service teachers, and $41.9 \%$ (103) were practicing teachers. Structural Equation Modeling (SEM) with the use of IBM SPSS Amos was performed to determine the estimates of the parameters of the study model. The study showed that the proposed model fulfilled the requirements of the predetermined fit index, showing Use Expectancy (UE), Facilitating Condition (FC), Social Influence (SI), and Mobile Teacher Efficacy (MTE) were significant factors of behavioral intention (BI). Overall, the analysis of SEM provided strong evidence that the variables of the study contributed to $69.8 \%$ of the variances in BI. Also, the findings showed that MTE influenced Behavioural Intention (BI) in the use of mobile heutagogy more strongly for practicing teachers than for pre-service teachers. The implication, this study is the proposed conceptual model can serve as a constructive guideline to help the stakeholders, notably the policymaker, professional development for teachers and to facilitate the implementation of mobile heutagogical practices.
\end{abstract}

* Corresponding author: Kung-Teck, Wong, email:thomas@fpm.upsi.edu.my 
Keywords: Acceptance model; mobile learning; Heutagogy; Structural Equation Modelling.

\section{Introduction}

In line with the requirements and challenges of 21st-century education, the instructional concept of national education needs to be redefined by taking learning contents, learning approaches, and educational technologies into account. In this regard, the Ministry of Education of Malaysia, Higher Education Department (JPT), through Amanat 2018, has introduced Education 4.0 (Edu. 4.0) (Kementerian Pengajian Tinggi, 2018). Edu. 4.0 is an educational transformation towards achieving Higher Education 4.0 in line with the Industrial Revolution 4.0 (4IR) and Malaysia Education Blueprint 2015-2025. According to Malaysian Higher Education Minister, PdP 4.0 requires four transformations, which are (i) Redesigning Learning Spaces, (ii) Fluid and Organic Curriculum, (iii) 21st Century Pedagogy, and (iv) Latest Learning \& Teaching Technologies.

In line with the urgent need for the four transformations underpin Edu. 4.0, it is pertinent to point out that new ways of pedagogical practices need to design and understand to welcome the new paradigm of Edu 4.0. Many recent surges in published studies on Mobile-Heutagogy (m-Heutagogy) with most studies being conducted in the West, (Blaschke, 2012; Blaschke \& Hase, 2016; Hase \& Kenyon, 2007; Ruslin Amir, Hamidun Bunawan \& Mohd Firdaus Yahaya, 2018) have revealed that M-Heutagogy has significant impacts on Edu. 4.0. Indeed, MHeutagogy is well documented for its succeeding in the online learning environment.

M-Heutagogy practices can be well-defined as a mobile-based self-determine concept which mirrors a real-world learning notion based on the integration of the conventional pedagogy learning concept and the heutagogical method. The concept, characteristics, and strengths of the m-heutagogy learning approach based on mobile learning have significantly popularized the use of the concept of blended learning, which has been widely acknowledged by practitioners to have a profound significance to student learning (Cimermanová, 2013; Songkram, 2015). Indeed, based on previous research, Blaschke (2012) and Eachempati, KS, Komattil and Ismail (2017), to create and cultivate 21st selfdetermined learners, Heutagogy is best implemented with the suitable latest learning and teaching technologies (Mobile Apps) such as Google Docs, ePortfolio, Twitter, Diigo, YouTube, Quizzes, MindMap and Wikipedia. Arguably, in line with the advancements of the mobile-technology related tools as education tools, mobile devices and various apps have empowers the use with the ability to interact via various social media interfaces for and in learning (Jin \& Cecilia, 2018; Nowak, 2019; Nam Thao, 2015; Marandu et al., 2019).

\section{The Study}

Teachers are one of the key players who can play help in educational technology integration practices. They should be conscious of the importance, advantages, 
and usability of the m-heutagogy in the process of transfer knowledge, skills, and attitudes to students. As part of their teaching responsibilities, teachers are expected to accept and implement such a technology-based learning approach to help educate the young generation of students especially related to the digital native. Digital natives are given by Prensky (2011). This generation is sensitive to the use of digital equipment, and they have used technology to do most activities all day. Furthermore, this group of people is growing up in the digital age and very aware of digital-related technologies tools. In the educational environment, Prensky (2011) has adopted the term "digital native" as a group of students who always use technology in a variety of daily activities and communicate using the language of technology, video and toy tools Technology as well as using the latest social media institutions to communicate with peers.

In view of the changing educational landscape, expectations, and hopes entrusted on teachers have intensified to create $21^{\text {st }}$ self-determined learners by exploiting and harnessing the capability of mobile learning. Arguably, the level of success of the integration of heutagogy practices relies on their desires and active involvements in such an effort (Çevik, Dağhan, Barin, \& Savran, 2015; Hoque, Ahmad Zabidi, \& Fatema Zohora, 2012; Stratton, 2014; Vatanartiran \& Karadeniz, 2015)

As revealed in previous studies, especially in the West, teachers have positive perceptions of and high confidence with the capability of ICT in enhancing student learning (Teo et al., 2019; Wong et al., 2019). Paradoxically, in developing countries, such as Malaysia, their use of m-heutagogy in the teaching practices was quite low, despite their high awareness of the benefits of mobile technology tools in the daily delivery pedagogical process.

The implementation of e-learning in Malaysian school settings seems to face the same predicament as evidenced by the low level of its use among teachers (Mohd Azli, Wong, \& Goh, 2016; Wong, Hwang, Goh \& Khadijah, 2018; Wong, Abdullah \& Goh, 2019). Such a problem has been confirmed by the Auditor-inGeneral Report (3rd Series) (Ministry of Finance of Malaysian, 2014), which clearly shows the1Bestarine project, especially the implementation of blended learning, was fraught with a host of issues, notably from the management and performance aspects. Given the critical responsibility of teachers in the progression of implementing m-Heutagogical practices and its synergies for them to cultivate and creating 21st self-determined pupils, and to make up the insufficiency of the information and understanding about $\mathrm{m}$-Huetagogical practices for creating $21^{\text {st }}$ self-determined pre-service teachers, explore and understand factors that influence behavioral intention (BI) of teachers in the implementation of heutagogy with the help of mobile technology educational tools is vital in the process of encouraging teachers to implement m-heutagogy in their everyday teaching and learning in classrooms. Indeed, the level of Mobile Heutagogy acceptance should be studied in-depth, as previous studies conducted in Malaysia have not shown enough clarification or judgments on how and why the teachers, either pre-service teachers or practicing teaching, in 
applying Mobile Heutagogy in teaching and learning (Eachempati, KS, Komattil \& Ismail, 2017; Malek, 2017).

Thus, this study aims to understand factors that were contributing the intention to integrate mobile related technology teaching tools in huetagogical practices among teachers in Malaysia contexts. Furthermore, the study also employed invariance multi-group structural model analysis to explore the different factors contributing to the use of mobile in heutogogy among teachers (preservice/practicing teachers). Finally, the Moblie-Heutagogical (M-Heutagogical) Acceptance and Use Model was created based on the data collected.

\section{Related Theoretical Review}

A theoretical review is vital to understand the concepts, theory, and definitions related to the topic of this study. Furthermore, it relates to the appropriateness, ease of application and explanatory power.

\subsection{Studies in technology acceptance in teaching and learning Acceptance Models}

To comprehend the user behaviors and behavioral intention of teachers toward integration of mobile in heutagogical practices, the researchers decided to adapt and adopt a study framework that was grounded on the models and theories of the socio-psychological field, in particular, those that are associated to user technology acceptance models and theories, namely Technology Acceptance Model (TAM) (Davis, Bagozzi, \& Warshaw, 1989), Theory of Reasoned Action (TRA) (Fishbein \& Ajzen, 1975), C-TAM-TPB (Taylor \& Todd, 1995, Theory of Planned Behavior (TPB) (Ajzen, 1991) and Unified Theory of Acceptance and Use of Technology (UTAUT) (Venkatesh et al., 2003). Among such models, TAM is one of the most widely used models to help explain individuals' acceptance of technology (Venkatesh et al., 2012). Davis (1989), known by its perceived ease of use (PEU) and perceived usefulness (PU), is considered as the main determinant of technology acceptance. Based on TAM, which was adapted from TRA, David defined PEU "the degree to which a person believes that using a particular system would be free of effort" (p. 320) and PU as "the degree to which a person believes that using a particular system would enhance his/her job performance" (p.320). To date, these two constructs have been widely used or adapted by almost all technology intention to use models.

Venkatesh et al. (2003) developed UTAUT based on Innovation Diffusion Theory (IDT) (Rogers, 1983), Social Cognitive Theory (SCT) (Bandura, 1989), Model of PC Utilization (MPCU) (Thompson, Higgins, \& Howell, 1991), and Motivational Model (MM) (Davis, Bagozzi, \& Warshaw, 1992). Clearly, such a model contains elements derived from empirical studies of several models of technology acceptance that highlight individual acceptance of the technology in teaching and learning. In principle, UTAUT consists of four main factorials that determine the intention to use technology, namely Performance Expectancy (PE), Social Influence (SI), Facilitating Conditions (FC), and Effort Expectancy (EE). The chronology of the developments of such models indicates that the 
domains among models are closely related and a relatively new model evolved from earlier models.

\subsection{Mobile-Heutagogy in Practices to cultivate 21 $1^{\text {st }}$ Self-Determined Learner}

The term heutagogy came into existence as early as 2000 in Australia (Hase \& Kenyon, 2000). Heutagogy is self-determined learning that rooted in andragogy and applied a holistic approach, such as a learner-centered approach (Blaschke, 2012; Hase \& Kenyon, 2000). The heutagogy begins with the Greek word "паvто," which means "self," while "gogy" means "learning about." Also known as self-determination learning (Blaschke \& Hase, 2019; Chacko, 2018; Hase \& Kenyon, 2007), which means that learners are free to determine their own learning, how they learn and how they prove that they have mastered the learning topics even though they still need the engagement of their teachers or instructors. Indeed, there has been a recent surge in published research on the impacts and advantages of integrate heutagogical practices in teaching and learning in the new paradigm of modern education (Amutha, 2015; Banerjee, 2019; Green \& Schlairet, 2017; Kamrozzaman et al., 2019).

Mobile Heutagogy is not a new concept of learning. The term 'mobile Heutagogy' came when academicians applied self-determined learning with any mobile applications or technologies to achieve learning objectives (Narayan \& Herrington, 2014). Mobile heutagogy, however, has been interpreted and given a wide range of meanings over time. Numerous studies define mobile. However, the definition of meaning in describing its characteristics is different because it is influenced by many other instructional factors.

Overall, mobile Heutogogy is self-determined learning that is rooted in andragogy and uses holistic approaches such as student-centered approaches and integration of mobile-related educational tools to enhance learning in $21^{\text {st }}$ teaching and learning. Mobile heutagogical practices improve critical thinking and reflection, increase learner motivation and engagement, and boost students' autonomy and control of their interest in and for learning with the help of mobile educational tools.

\section{Research Model and Objectives}

The figure shows the relationships among the variables of technology acceptance models. According to the adapted relationships among variables, the researchers formulated several main research objectives and hypotheses.

a) To develop an instrument to understand the intention to implement mobileHeutagogical practices among pre-service teachers and practicing teachers.

b) To develop a measurement model to explain factors that contribute to the intention to implement mobile-Heutagogical practices among pre-service teachers and practicing teachers.

c) Examining the multi-group effects and its different between pre-service teachers and practicing teacher's intention to implement mobileHeutagogical. 


\section{Research Hypothesis}

Five (5) research hypotheses were formulated:

H1: Mobile Teacher Efficacy (MTE) significantly influences pre-service and practicing teachers' behavioral intention (BI) in the integrating of mobile heutagogical practicing in teaching and learning.

H2: Use Expectancy (UE) significantly influences pre-service and practicing teachers' behavioral intention (BI) in the integrating of mobile heutagogical practicing in teaching and learning.

H3: Social Influence (SI) significantly influences pre-service and practicing teachers' behavioral intention (BI) in the integrating of mobile heutagogical practicing in teaching and learning.

H4: Facilitating Condition (FC) significantly influences pre-service and practicing teachers' behavioral intention (BI) in the integrating of mobile heutagogical practicing in teaching and learning.

H5: Mobile Teacher Efficacy (MTE), Facilitating condition (FC), Use Expectancy (UE), and Social influence (SI) influences Behavioural Intention (BI) of mobile heutagogical practices more strongly for pre-service teachers than for practicing teachers.

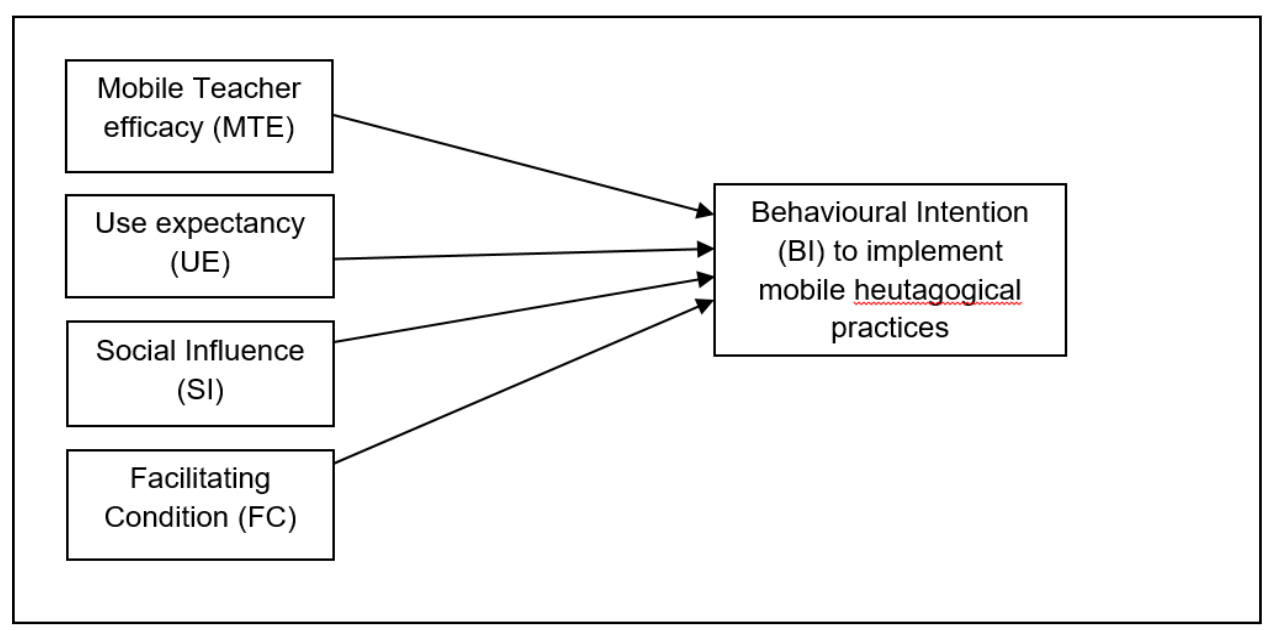

Figure 1. The conceptual framework of the study

\section{Research Method}

\subsection{Research design}

In this study, data were collected with a survey question consisting of items on sample's demographics and items measuring the exogenous and endogenous variable (Mobile Teacher Efficacy; Social Influence (SI); Use Expectancy (UE); Facilitating Condition (FC) and Behavioral Intention (BI) as reflected in Figure 1). Methodologically, the study has employed SEM (Structural equation modelling) - AMOS 23.0 as the main analysis software to test the suggested research model. Maximum Likehood Extimation (MLE) was carried out to estimate the parameters of the suggested model. There is a growing corpus of research employed SEM in understanding the relationship between the exogenous and endogenous variables and test the model fit. Indeed, SEM is 
commonly used in research in previous studies in order to understand the effects and its causal relationships between the studied variables, developing model and effects of the moderating factors especially in educational technologies setting (Wong et al.,-2018; Wong, Abdullah \& Goh, 2019).

\subsection{Participants and data collection}

The study sample consisted of 246 teachers; they were pre-service and practicing teachers from various teacher education institutions and universities and schools throughout Malaysia. Most of the participating teachers were females, 193 (78.6\%). Moreover, only $6.1 \%$ of the respondents were over 40 years old. Among these participants, $58.1 \%$ (143) were pre-service teachers, and $41.9 \%$ (103) were practicing teachers. On average, their teaching experiences ranged from 10 to 15 years. Participation by the preschool teachers was wholly voluntary. Approximately 30 minutes of allocation time has been given to the participants to complete the self-report survey question. Slightly more than half of the respondents $(76.0 \%)$ held two posts or more in their school. In terms of the school category, the percentages of teachers from urban schools and rural schools were almost the same, which were at $42.8 \%$ and $48.2 \%$, respectively. Out of 246 participating pre-service teachers and practicing teachers, 199 participants filled out the self-report survey questions in printed form while the remaining participants filled out the online questionnaire.

\subsection{Instrument}

A self-report survey question was created to answer the objectives of this study. The survey question consisted of five (5) variables. A total of 20 items related to Mobile Teacher Efficacy, Social Influence (SI), Use Expectancy (UE), Facilitating Condition (FC), and endogenous variables was Behavioral Intention (BI) were used to collect the data and the questionnaire was presented in bilingual English and Malay Language. This was to ensure all participants able to understand and achieve higher validity and reliability of the findings.

The items were adapted and adopted from previous related studies on technology acceptance and intention to integrate ICT in educational settings. Pilot testing was carried out to understand its reliability. A total of 47 preservice and practicing school teachers were invited for the pilot analysis. The Cronbach's alpha were 0.88 for Use Expectancy (EE); 0.87 for Mobile Teacher Efficacy (MTE); 0.88 for Social Influence (SS); 0.98 for Facilitating Condition (FC); and 0.91 for Behavioral Intention (BI). According to the results, all the items have reached the minimum required threshold value of satisfactory reliability.

\section{Data Analysis and Findings}

In this study, IBM SPSS AMOS (Analysis of Moment Structures) Version 23.0 was employed to analyze the research data based on the Structural Equation Modeling (SEM) technique. Specifically, the relationships and their covariance of exogenous and endogenous variables were assessed via SEM (Tabachnick \& Fidell, 2007). Such a covariance-based technique was used to test the proposed model of the relationships of the five (5) variables of the study, namely Facilitating Condition (FC); Mobile Teacher Efficacy, Social Influence (SI), Use 
Expectancy (UE), and Behavioral Intention (BI). These variables were estimated and measured to determine their values of significance in testing the research hypotheses.

Essentially, the analysis of SEM involves two stages (Schumacker \& Lomax, 2010), namely the validation of the measurement model and, thereafter assess its structural model, which are carried out in sequence. The first stage involves estimating and validating the measurement model with the following aims: (i) to test the extent to which a measured variable can be represented by a construct of a study, (ii) to determine the validity of discriminants, (iii) to assess the reliability of the proposed measurement model, and (iv) to determine the basis relationship between study variables.

\subsection{Measurement model validation}

Confirmatory factor analysis (CFA) was employed to identify the five (5) constructs factor loading, as suggested in the proposed model. Based on Table 1 (Measurement Model), it is indicated that factor loadings of the 20 items (Mobile Teacher Efficacy (MTE), Social Influence (SI), Use Expectancy (UE), Facilitating Condition (FC), and the endogenous Behavioral Intention (BI) were all above 0.50 .

For each factor-loading item for the constructs, it has been proven that the items explained in between $66 \%$ to $87 \%$ of the variances explained by the proposed variables. It has also been found that the results of the principal component analysis (PCA) indicated SI, UE, FC, MTE, and BI variables, as presented in Table 1, explicated $72.2 \%$ of the overall variance of the proposed model.

The convergent validity of the proposed measurement model was established via composite reliability (CR) and average variance extracted (AVE). Based on the values of $\mathrm{AVE}$, the proposed measurement model fulfilled the minimum requirements for running structural equation modelling (SEM) analysis. Composite reliability for all the variables were ranging from 0.83 to 0.92 , and it has exceeded the threshold value (0.05).

Table 1. Results of the measurement model

\begin{tabular}{|l|l|l|l|l|}
\hline $\begin{array}{l}\text { Latent } \\
\text { Variable }\end{array}$ & Item & $\begin{array}{l}\text { Factor } \\
\text { Loading }\end{array}$ & $\begin{array}{l}\text { Average Variance } \\
\text { Extracted }^{b}(\geq .50)^{*}\end{array}$ & $\begin{array}{l}\text { Composite } \\
\text { Reliability }^{c}(\geq .50)^{*}\end{array}$ \\
\hline \multirow{4}{*}{$\mathrm{BI}$} & $\mathrm{B} 1 \mathrm{1}$ & 0.80 & .62 & .83 \\
\cline { 2 - 3 } & $\mathrm{B} 12$ & 0.89 & & \\
\cline { 2 - 3 } & $\mathrm{B} 13$ & 0.65 & & .92 \\
\hline \multirow{4}{*}{$\begin{array}{l}\text { MTE } \\
\text { Teacher } \\
\text { Efficacy) }\end{array}$} & MTE1 & 0.83 & .70 & \\
\cline { 2 - 3 } & MTE2 & 0.87 & & \\
\cline { 2 - 3 } & MTE3 & 0.81 & & \\
\cline { 2 - 3 } & MTE4 & 0.83 & & \\
\cline { 2 - 3 } & MTE5 & 0.83 & & \\
\hline
\end{tabular}




\begin{tabular}{|l|l|l|l|l|}
\hline \multirow{4}{*}{$\begin{array}{l}\text { UE } \\
\text { (Use }\end{array}$} & UE1 & 0.70 & .58 & .85 \\
\cline { 2 - 3 } & UE2 & 0.75 & & \\
\cline { 2 - 3 } & UE3 & 0.74 & & \\
\cline { 2 - 3 } SI & UE4 & 0.84 & & \\
(Social & SI1 & 0.71 & .54 & .83 \\
\cline { 2 - 3 } Influence) & SI & 0.82 & & \\
\cline { 2 - 3 } FC & SI & 0.76 & & \\
SI & 0.66 & & \\
(Facilitating & FC1 & 0.68 & .62 & \\
\cline { 2 - 3 } Condition) & FC2 & 0.88 & & \\
\cline { 2 - 3 } & FC3 & 0.81 & & \\
\cline { 2 - 3 } & FC4 & 0.77 & & \\
\hline
\end{tabular}

The Discriminant Validity (DV) results were presented in Table 2. Based on the findings from DV, it has been indicated that discriminant validity has existed in the proposed model, as shown in Table 2. According to the table below, the diagonal in parentheses was the square-root of average variances extracted from the observed and unobserved constructs. Whereas, the off-diagonal referred to the correlations between constructs.

Table 2. Discriminant validity for the measurement model

\begin{tabular}{|l|l|l|l|l|l|}
\cline { 2 - 6 } \multicolumn{1}{c|}{} & FC & UE & MTE & SI & BI \\
\hline FC & $(0.79)$ & & & & \\
\hline UE & 0.48 & $(0.76)$ & & & \\
\hline MTE & 0.30 & 0.38 & $(0.83)$ & & \\
\hline SI & 0.42 & 0.32 & 0.28 & $(0.74)$ & \\
\hline BI & 0.52 & 0.45 & 0.60 & 0.35 & $(0.79)$ \\
\hline
\end{tabular}

\subsection{Testing of Measurement Model and Structural Model}

Structural Equation Model (SEM) analysis was carried out to understand and assess the proposed measurement model and its structural model based on the data collected. Software AMOS 23.0 has been utilized for these testings.

The goodness-of-fit models were checked by using five absolute fit indices. The five absolute fit indices are (a) ratio of $\chi^{2}$ to its degree of freedom $\left(\chi^{2} / \mathrm{df}\right)$; (b) Standardised Root Mean Square Error of Approximation (RMSEA); (c) Comparative Fit Index (CFI); (d) Goodness of Fit (GFI); and (d) Tucker-Lewis Index (TLI). Those goodness-of-fit indices are commonly employed in the process of identifying the measurement model and structural model fit (Mohd Azli et al., 2019).

Based on Hair et al. (2017), if the CFI and GFI values are lower than 0.95, the RMSEA value should be $<0.05$. The value below 3 for $\chi^{2} / d f$ is reflected acceptable fit value. The initial results from the measurement model revealed an 
acceptable model fit. For structural model, the value for $\chi^{2}$ Statistic $=243.110$; $\chi^{2} / \mathrm{df}=1.52 ; \mathrm{GFI}=.92 ; \mathrm{CFI}=.97 ; \mathrm{RMSEA}=.05 ; \mathrm{TLI}=.97$. The results have revealed that all of the items in the proposed measurement model were reliable for structural equation model testing. Table 3 gives the results of the test and it is proven that the proposed model is fit as all values are within the acceptable thresholds recommend by Hair et al. (2017).

Table 3. The measurement model and structural model of fit indices

\begin{tabular}{|c|c|c|c|}
\hline Fit indices & $\begin{array}{l}\text { Values of } \\
\text { measurement } \\
\text { model }\end{array}$ & $\begin{array}{l}\text { Values of } \\
\text { structural model }\end{array}$ & Criteriaa $^{a}$ \\
\hline$\chi^{2}$ Statistic & $233.504^{* *}$ & $243.110^{\star *}$ & $\begin{array}{l}p \text {-value with } \\
\text { significance }\end{array}$ \\
\hline$x^{2} / d f$ & 1.49 & 1.52 & $<3$ \\
\hline RMSEA & 0.04 & 0.05 & $<0.08$ \\
\hline GFI & 0.91 & 0.92 & $\geq 0.90$ \\
\hline CFI & 0.97 & 0.97 & $\geq 0.90$ \\
\hline TLI & 0.97 & 0.96 & $\geq 0.90$ \\
\hline
\end{tabular}

a Based on Hair et al. (2017)

$* * p<.01$.

\section{Hypothesis Testing and Discussion}

The hypothesised proposed model and its path parameter estimates for each construct were performed in Table 4. Hypotheses H1, H2, H3, and H4 were supported by the collected data. Mobile Teacher Efficacy (MTE) as exogenous variable shows significant influence on Behavioural intention (BI) $(\beta=.40$, $\mathrm{p}<.00)$, Use Expectancy (UE) $(\beta=.22, \mathrm{p}<.00)$, Social Influence (SI) $(\beta=.23, \mathrm{p}<.00)$, Facilitating Condition $(\mathrm{FC})(\beta=.27, \mathrm{p}<.00)$. Based on the findings, teachers' behavioural intention to use mobile heutagogy in teaching and learning was found to be significantly predicted by Mobile Teacher Efficacy (MTE), Use Expectancy (UE), Social Influence (SI), Facilitating Condition (FC), resulting in an $R^{2}$ of .698. This indicated that all four exogenous variables (Mobile Teacher Efficacy (MTE), Use Expectancy (UE), Social Influence (SI), and Facilitating Condition (FC)) have explained $69.8 \%$ of the variance in pre-service teachers and practicing teachers' behavioural intention use of mobile heutagogy for teaching. 
Table 4. Hypothesis testing results

\begin{tabular}{lllll}
\hline $\begin{array}{l}\text { Hypothe } \\
\text {-ses }\end{array}$ & Path & $\begin{array}{l}\text { Path } \\
\text { Coefficient }\end{array}$ & Hypothesis & Directions \\
\hline H1 & MTE $\rightarrow$ BI & $.40^{* *}$ & Significant & Positive(+) \\
H2 & UE $\rightarrow$ BI & $.22^{* *}$ & Significant & Positive(+) \\
H3 & SI $\rightarrow$ BI & $.23^{*}$ & Significant & Positive(+) \\
H4 & FC $\rightarrow$ BI & $.27^{* *}$ & Significant & Positive(+)
\end{tabular}

In order to test and examine confidence intervals differences between preservice teachers vs. practicing teachers, the invariance analysis was carried out. In this analysis, the sub-group analysis has been done to identify its differences by constraining the path-by-path analysis for both groups. The path-by-path comparison analysis was carried out to understand and examine the relationships between $\mathrm{MTE} \rightarrow \mathrm{BI}$; $\mathrm{UE} \rightarrow \mathrm{BI}$; $\mathrm{FC} \rightarrow \mathrm{BI}$; and $\mathrm{SI} \rightarrow \mathrm{BI}$ ) its differences among pre-service teachers and practicing teachers. The $\chi^{2}$ of path-by-path results were compared with $\chi^{2}$ of the unconstrained model $\left(\Delta \chi^{2}\right)$.

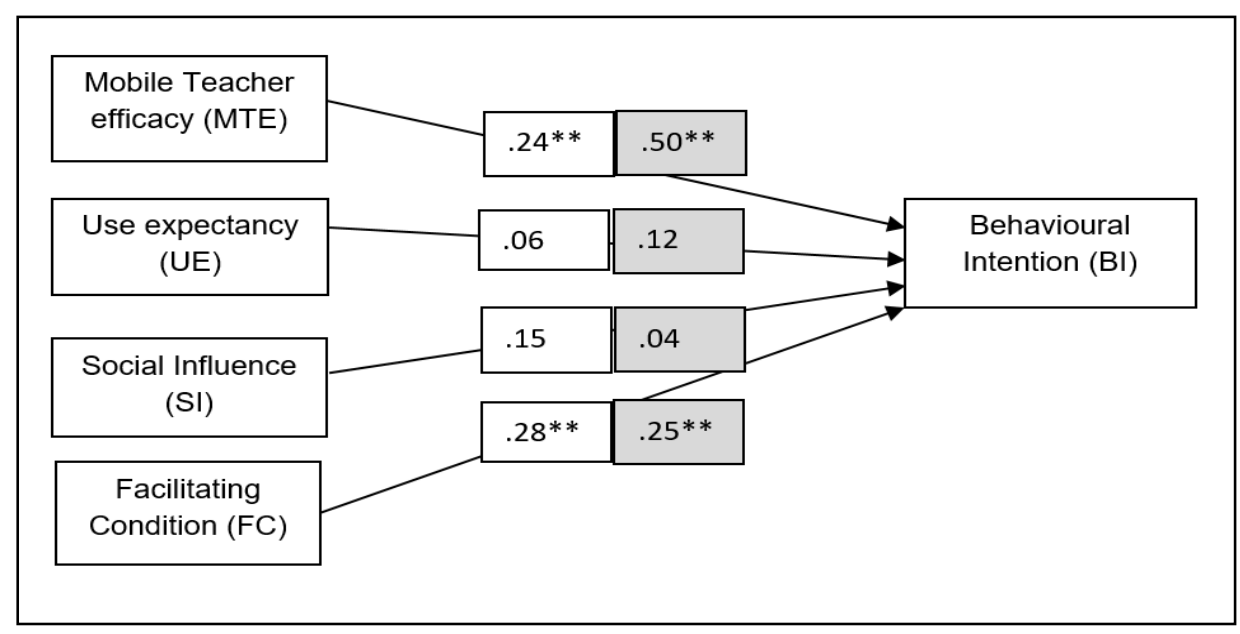

Figure 2. Significant differences standardised path coefficients for pre-service teachers and practicing teachers. Coefficients for practising teachers are in the grey shaded boxes.

Table 5. Path-by-path comparison for the pre-service teachers and practicing teachers

\begin{tabular}{|l|c|c|c|}
\hline & $\chi^{2}$ & $D f$ & $\begin{array}{c}\Delta \chi^{2} \text { from } \\
\text { unconstrained model }\end{array}$ \\
\hline $\begin{array}{l}\text { Unconstrained } \\
\text { modol }\end{array}$ & 480.968 & 320 & $237.063^{* *}$ \\
\hline Fully Constrained & 243.905 & 160 & \\
\hline Constrained paths & & & \\
\hline \multicolumn{1}{|c|}{ MTE $\rightarrow$ BI } & 485.724 & 321 & $4.756^{* *}$ \\
\hline
\end{tabular}




\begin{tabular}{|c|c|c|c|}
\hline UE $\rightarrow$ BI & 481.462 & 321 & $0.49(n . s)$ \\
\hline SI $\rightarrow$ BI & 482.230 & 321 & $1.26(n, s)$ \\
\hline FC $\rightarrow$ BI & 481.026 & 321 & $0.05^{*}$ \\
\hline
\end{tabular}

$90 \% \chi^{2}$ thresholds $=483.67 ; 95 \% \chi^{2}$ thresholds $=484.81 ; 99 \% \chi^{2}$ thresholds $=$ 487.60; (ns) $=$ not significant; ${ }^{* *} \mathrm{p}<.01 ;{ }^{*} \mathrm{p}<.05$

The results of the analyses of pre-service teachers and practicing teachers were shown in Figure 2 and Table 5. Unexpectedly, UE $\rightarrow$ BI and SI $\rightarrow$ BI were found to be not significantly different. Having that, it revealed that the path coefficients for $\mathrm{UE} \rightarrow \mathrm{BI}$ and $\mathrm{SI} \rightarrow \mathrm{BI}$ did not show any difference between pre-service teachers and practicing teachers. In detail, the results shown that Mobile teacher efficacy (MTE) influenced Behavioural Intention (BI) in the use of mobile heutagogy for teaching and learning more strongly for practicing teachers than for pre-service teachers. On the other hand, Facilitating Conditions (FC) influenced BI more strongly for pre-service teachers than for practicing teachers in the use of mobile heutagogical practices. Thus, hypothesis H5 was partially supported in this study.

\section{Limitation and recommendations future research}

Some primary limitations mirror the need for further investigations. First, selfreporting items were used in this study, thus suggesting the possibility of bias in the outputs of the study due to participants may have heterogeneous of $\mathrm{m}$ heutagogy knowledge and skills, various types of mobile learning tools in the markets. Second, there are no known comprehensive theories and models by local scholars that can provide an explicit basis in explaining m-heutagogy. Theories and models that were conceptualized by western scholars have been adopted and adapted to give a possible theoretical foundation of the study. Thus, cross-cultural differences are assumed in this study.

\section{Conclusion}

The purpose of this study is to explore and understand contributing factors that influence Behavioral Intention (BI) of pre-service teachers and practicing teachers in the integration of mobile-related educational technology tools in heutagogical practices in their everyday teaching and learning in classrooms. Thereafter, develop and evaluate a model that explains factors that contribute to the intention to implement mobile-Heutagogical practices among pre-service teachers and practicing teachers.

Overall, the research findings showed that the independent variables of the study (Mobile Teacher Efficacy (MTE), Use Expectancy (UE), Social Influence (SI), and Facilitating Condition (FC)) have explained $69.8 \%$ of the variance in pre-service teachers and practicing teachers' behavioural intention use of mobile heutagogy for teaching. Also, the analysis of SEM showed that the proposed model in this study had a high model fit index, indicating that it could help explain the relationships of such factors in influencing BI of teachers in using mobile heutagogy in teaching and learning. 
Specifically, the results of SEM analysis showed that MTE, UE, SI, and FC had significant direct effects on BI of teachers in using the mobile heutagogy learning approach. Such findings are consistent with the findings of previous studies. (Abu-Al-Aish \& Love, 2013; Attuquayefio \& Addo, 2014; Teo, Fan, \& Du, 2015; Wong, Abdullah \& Goh, 2019; Wong, Teo \& Russo, 2013; Wong et al., 2019) that focused on technology acceptance models, such as TAM, C-TAM-TPB, TAM2, and UTAUT. Based on the analysis of direct effects, it could be argued that teachers with positive UE (indicating that the use of the mobile heutagogical practices approach could help improve student learning and their teaching practice) would have a greater inclination to accept and use such a teaching approach. The opposite would be true for those with poor UE. Noticeably, teachers' intention to implement mobile in heutagogy learning would intensify when they believe that its implementation would improve the learning process.

The unexpected vital and interesting finding was that the study also found that MTE has stronger influences towards BI among practicing teachers in the use of mobile heutagogical practices. One of the most promising reasons is most of the pre-service teachers are from Generation $\mathrm{Y}$ and $\mathrm{Z}$. They are related to digital natives, as given by Prensky (2001). This generation is sensitive to the use of digital equipment, and they have used technology to do most activities all day. Indeed, they always use technology in a variety of daily activities and communicate using the language of technology, and using the latest social media institutions to communicate with peers. On this basis, pre-service teachers did not feel the importance of MTE in the use of mobile heutagogical practices.

\section{Acknowledgment}

Thanks are given to Universiti Pendidikan Sultan Idris (UPSI), Perak, Malaysia, for the Rising Star grant (2019-0122-107-01).

\section{References}

Abu Al-Aish, A., \& Love, S. (2013). Factors influencing students' acceptance of Mlearning: An investigation in higher education. International Review of Research in Open and Distance Learning, 14(5), 82-107. doi:10.19173/irrodlv14i5.1631

Ajzen, I. (1991). The Theory of Planned Behavior. Organizational Behavior and Human Decision Processes, 50, 179-211.

Amanat 2018 Menteri Pendidikan Tinggi. (2018). Kementerian Pengajian Tinggi.

Amir, R., Bunawan, H., \& Yahaya, M. F. (2018). Cabaran mahasiswa dan kolej kediaman mendepani Revolusi Industri 4.0 [Student and residential college challenges facing the Industrial Revolution 4.0]. Governans, Institusi \& Pengurusan Kewangan: Prosiding Konvensyen Kepengetuaan dan Felo Penghuni Kolej Kediaman Universiti Awam Kebangsaan 2018, 3, 24-29.

Attuquayefio, S., \& Addo, H. (2014). Using the UTAUT model to analyze students' ICT adoption. The International Journal of Education and Development using Information and Communication Technology, 10(3), 75-86.

Banerjee, P. (2019). Heautagogy: A self-determined approach enhances constructivism. International Journal of Scientific Research and Review, 7(6), 223-230. 
Blaschke, L. M. (2012). Heutagogy and lifelong learning: A Review of heutagogical practice and self-determined learning. International Review of Research in Open and Distance Learning, 13(1), 56-71. doi:10.19173/irrodl.v13i1.1076

Blaschke, L. M., \& Hase, S. (2016). Heutagogy: A holistic framework for creating 21st century self-determined learners. In The Future of Ubiquitous Learning: Learning Designs for Emerging Pedagogies (pp. 25-40). Berlin, Heidelberg: Spring Verlag. doi:10.1007/978-3-662-47724-3-2

Blaschke, L. M., \& Hase, S. (2019). Heutagogy and digital media networks: Setting students on the path to lifelong learning. Pacific Journal of Technology Enhanced Learning, 1(1), 1-14. doi:10.24135/pjtel.v1i1.1

Cevik, Y. D., Daghan, G., Barin, S., \& Savran, R. (2015). Examining information and communication technologies preservice teachers' views on technology integration and their roles in this process. Journal of Theory and Practice in Education, 11(4), 1143-1166. doi:10.17244/eku.12644

Chacko, T. (2018). Emerging pedagogies for effective adult learning: From andragogy to heutagogy. Archives of Medicine and Health Sciences, 6(2), 278-283. doi:10.4103/amhs.amhs_141_18

Cimermanová, I. (2013). Teacher training in the virtual learning environment. International Journal of Arts and Commerce, 2(10), 1-8.

Davis, F. D., Bagozzi, R. P., \& Warshaw, P. R. (1989). User acceptance of computer technology: A comparison of two theoretical models. Management Science, 35(8) doi:10.1287/mnsc.35.8.982

Fishbein, M. A., \& Ajzen, I. (1975). Belief, attitude, intention and behaviour: An introduction to theory and research. Reading, MA: Addison-Wesley. doi:10.2307/2065853

Green, R., \& Schlairet, M. (2016). Moving toward heutagogical learning: Illuminating undergraduate nursing students' experiences in a flipped classroom. Nurse education today, 49, 122-128. doi:10.1016/j.nedt.2016.11.016

Hair, J. F., Babin, B. J., \& Krey, N. (2017). Covariance-based structural equation modeling in the Journal of Advertising: Review and recommendations. Journal of Advertising, 46(1), 163-177. doi:10.1080/00913367.2017.1281777

Hase, S., \& Kenyon, C. (2000). From andragogy to heutagogy. ultiBASE In-Site.

Hase, S., \& Kenyon, C. (2007). Heutagogy: A child of complexity yheory. Complicity: An International Journal of Complexity and Education,4(1), 111-118. doi:10.29173/cmplct8766

Hoque, K. E., Abdul Razak, A. Z., \& Mosa, F. Z. (2012). ICT Utilization among school teachers and principals in Malaysia. International Journal of Academic Research in Progressive Education and Development, 1(4), 17-34.

Jin, W., \& Junio-Sabio, C. (2018). Potential use of mobile devices in selected public senior high schools in the city of Manila Philippines. International Journal of Learning, Teaching and Educational Research, 17(4), 102-114. doi:10.26803/ijlter.17.4.7

Kamrozzaman, N. A., Badusah, J., \& Wan Mohammad, W. M. R. (2019). Heutagogy approach: Effectiveness of M-learning for lifelong learning education/Pendekatan heutagogi: Keberkesanan M-pembelajaran untuk pendidikan sepanjang hayat. Sains Humanika, 11(3), 53-61. doi:10.11113/sh.v11n3.1496

Merandu, E. E., Makudza, F., \& Ngwenya, S. N. (2019). Predicting students' intention and actual use of E-learning using the technology acceptance model: A case from Zimbabwe.International Journal of Learning, Teaching and Educational Research, 18(6), 110-127. doi:10.26803/ijlter.18.6.7

Nam, N. D., \& Thao, T. T. P. (2015). An empirical research on the use of mobile phones to support students' mathematics learning. International Journal of Learning, Teaching 
and Educational Research, 12(1), 133-141.

Narayan, V., Herrington, J., \& Cochrane, T. (2019). Design principles for heutagogical learning: Implementing student-determined learning with mobile and social media tools. Australasian Journal of Educational Technology, 35(3), 86-101. doi:10.14742/ajet.3941

Nowak, B. M. (2019). The sense of self-efficacy of teachers working in special schools - A Research Communiqué. International Journal of Learning, Teaching and Educational Research, 18(10), 161-174. doi:10.26803/ijlter.18.10.10

Prashanti, E., KS, K. K., Komattil, R., \& Ismail, A. R. (2017). Heutagogy through Facebook for the millennial learners. MedEdPublish, 6 .

Prensky, M. (2001). Digital Natives, Digital Immigrants. On the Horizon, 9(5), 1-6. doi:10.1108/10748120110424816

Prensky, M. (2011). In the 21st-century university, let's ban (paper) books. Chronicle of Higher Education.

Sambandamurthi, A. (2015). Impact of integrating heutagogy into e-content gor tertiary learners. Pyrex Journals, 1(5), 52-56. Retrieved from http://www.pyrexjournals.org/pjerr

Schumaker, R. E., \& Lomax, R. G. (2010). A beginner's guide to structural equation modeling (3rd ed.). Mahwah, NJ: Routledge.

Songkram, N. (2015). E-learning system in virtual learning environment to develop creative thinking for learners in higher education. Procedia - Social and Behavioral Sciences, 174, 674-679. doi:10.1016/j.sbspro.2015.01.600

Stratton, T. M. (2014). A case study of the integration of 21st century technology within the place-based, Expeditionary Learning Outward Bound (ELOB) approach to education. Instructional Technology Education Specialist Research Papers, 16, 1-59. Retrieved from http://digitalcommons.georgiasouthern.edu/edu-papers/16

Tabachnick, B. G., \& Fidell, L. S. (2007). Using multivariate statistics. Boston: Pearson Education. Inc.

Taylor, S., \& Todd, P. A. (1995). Understanding information technology usage: A test of competing models. Information systems research, 6(2), 144-176.

Teo, T., Fan, X., \& Du, J. (2015). Technology acceptance among pre-service teachers: Does gender matter? Australasian Journal of Educational Technology, 31(3), 235-251. doi:10.14742/ajet.1672

Vatanartiran, S., \& Karadeniz, S. (2015). A needs analysis for technology integration plan: Challenges and needs of teachers. Contemporary Educational Psychology, 6(3), 206-220.

Ventakesh, V., Morris, M. G., Davis, G. B., \& Davis, F. D. (2003). User Acceptance of Information Technology: Toward a Unified View. MIS Quarterly, 27(3), 425-478.

Venkatesh, V., Thong, J. Y. L., \& Xu, X. (2012). Consumer Acceptance and Use of Information Technology: Extending the Unified Theory of Acceptance and Use of Technology. MIS Quarterly, 36(1), 157-178.

Wong, K. T., Hwang, G. J., Goh, P. S. C., \& Mohd Arif, S. K. (2018). Effects of blended learning pedagogical practices on students' motivation and autonomy for the teaching of short stories in upper secondary English. Interactive Learning Environments, 1-14. doi:10.1080/10494820.2018.1542318

Wong, K. T., Teo, T., \& Russo, S. (2013). Interactive whiteboard acceptance: Applicability of the UTAUT model to student teachers. The Asia-Pacific Education Researcher, 22(1), 1-10. doi:10.1007/s40299-012-0001-9

Wong, K. T., Abdullah, N., \& Abas, N. A. H. (2019). Blended learning pedagogical practices: The challenges to cultivate new ways of teaching in higher education 
institutions and universities. International Journal of Engineering and Advanced Technology, 9(1), 4178-4184. doi:10.35940/ijeat.a1427.109119

Wong, K. T., Abdullah, N., \& Goh, P. S. C. (2019). A cross examination of the intention to integrate MOOCs in teaching and learning: An application of multi-group invariance analysis. International Journal of Emerging Technologies in Learning (iJET), 14(19), 106-116. doi:10.3991/ijet.v14i19.10642

Yeop, M. A., Mohd Yaakob, M. F., Wong, K. T., \& Don, Y. (2019). Implementation of ICT policy (Blended Learning Approach): Investigating factors of behavioural intention and use behaviour. International Journal of Instruction, 12(1). doi:10.29333/iji.2019.12149a

Yeop, M. A., Wong, K. T., \& Goh, P. S. C. (2016). Blended learning: pedagogy, learning styles, and assessment activities in the classroom. International Journal of Advanced and Applied Sciences, 33(11), 36-39. doi:10.21833/ijaas.2016.11.007 